\title{
Pengembangan Produk Spring Steel Menggunakan Kerangka Kerja Quality Function Deployment (QFD)
}

\author{
Mohamad Jihan Shofa*1, Fauzul Iman ${ }^{2}$ \\ ${ }^{1,2}$ Program Studi Teknik Industri, Fakultas Teknik, Universitas Serang Raya \\ ${ }^{1,2} \mathrm{Jl}$. Serang-Cilegon Km. 5, Serang, 42111, Banten, Indonesia
}

\section{DOI:10.20961/performa.19.1.42164}

\begin{abstract}
Abstrak
Permintaan produk spring steel - sebagai penambat rel kereta api - masih sangat besar. Namun kondisi pasar domestik di Indonesia saat ini belum mampu memenuhi kebutuhan produk spring steel, sehingga sebagian besar produk tersebut bersumber dari hasil impor. Sebagai upaya pemenuhan terhadap permintaan pelanggan perlu dilakukan pengembangan produk yang dapat menghasilkan spring steel sesuai dengan spesifikasi yang diinginkan konsumen dan sesuai standar yang ditargetkan. Penelitian ini bertujuan untuk mengusulkan produk pengembangan produk spring steel dari material sisa (scrap) HRC tipe SPHC dan SS400. Pendekatan yang dilakukan adalah dengan menggunakan metode Quality Function Deployment (QFD) di mana tahapan yang dilakukan ada tujuh tahapan utama. Metode pengambilan data menggunakan survei, studi standar internasional yang digunakan dalam pengujian dan focused group discussion dengan $R \& D$ dan project engineer dari konsumen dan perusahan pengembang. Hasil penelitian ini adalah pengembangan produk spring steel dapat dilakukan dengan baik menggunakan kerangka QFD untuk memenuhi kebutuhan konsumen.
\end{abstract}

Kata kunci: Pengembangan produk, Spring steel, Quality function deployment.

\begin{abstract}
Market demand for spring steel-as a railroad anchor-is on high level but the domestic producer in Indonesia is still in the lack of product existance to fullfill its requirements. So that, the material sources comes from the abroad country supplier. To fullfill the customer demand for spring steels, manufactures needs product development to create spring steel refers to specifications based on customer needs and tehnical standards. This research objective is how to propose product development for spring steel from material scrap of HRC both of SPHC type and SS400 type. The approach method using Quality Function Deployment (QFD) in which consist of seven primary steps. Data collecting with survey, literature study about international standard requirements and focused group discussion with $R \& D$ dan project engineer from both of the customer and producer. The result is QFD framework can be applied for developing spring steel products as follow the customer needs.
\end{abstract}

Keywords: Product development, Spring steel, Quality function deployment.

\section{Pendahuluan}

Inovasi bisnis menjadi hal yang diperbincangkan pada era saat ini. Inovasi mampu menghasilkan kualitas yang lebih baik, organisasi yang efisien, biaya yang terkontrol, produk baru dan berbagai tuntutan yang sesuai dengan kebutuhan pasar dengan bagian utama inovasi yaitu sesuatu yang unik (Polak \& Jurczyk-Bunkowska, 2017). Inovasi dapat memberikan peluang bagi keberhasilan perusahaan untuk meningkatkan loyalitas konsumen, menambah konsumen baru atau memperbesar target pasar. Namun untuk mendapatkan peluang tersebut memang diperlukan usaha yaitu mewujudkan keinginan konsumen secara lebih cepat dibandingkan dengan kompetitor lainnya (Aleshkov, Zhebo, Kalenik, \& Solovev, 2019).

Salah satu upaya yang dilakukan adalah dengan melakukan inovasi produk. Inovasi produk tersebut dilakukan dengan berbagai tahapan pengembangan produk yang sistematis. Pengembangan produk diartikan sebagai sebuah transformasi dari peluang pasar dan berbagai asumsi terkait dengan teknologi produk yang mampu menghasilkan produk yang dapat diterima oleh pasar (Krishnan \& Ulrich, 2001). Oleh karena itu, inovasi produk merupakan upaya sistematis terkait pengembangan produk yang dapat diterima sesuai dengan kebutuhan kosumen.

Spring steel merupakan produk yang digunakan sebagai penambat rel kereta api. Kebutuhan material spring steel SUP9A untuk industri di Indonesia masih relatif besar, namun jumlah pemasok yang menghasilkan produk tersebut masih sedikit. Hal ini tentu menjadi peluang bagi perusahaan di Indonesia untuk mengembangkan produk tersebut. Ditambah lagi dengan kondisi indutri baja saat ini, banyak ditemukan sisa (scrap) yang berasal dari material dasar HRC tipe SPHC dan SS400 yang belum dimanfaatkan dengan baik.

*Corresponding author: m.j.shofa@gmail.com 
Material dasar tersebut dapat digunakan untuk menghasilkan komposisi kimia dengan sifat kimia dan mekanis sesuai spring steel SUP9A. Oleh karena itu perlu dilakukan pengembangan produk spring steel berbahan baku dari material scrap HRC tersebut dalam rangka mengambil peluang pasar yang ada.

Untuk mengembangkan produk spring steel membutuhkan pemahaman yang baik terhadap keinginan konsumen (voice of customers), di mana keinginan konsumen tersebut terdiri dari keinginan yang tampak dan tidak tampak (laten). Untuk mendapatkan keinginan konsumen tersebut diperlukan metode yang mampu mengetahui keinginan pelanggan dan persepsi pelanggan dengan baik, kemudian menerjemahkannya ke dalam spesifikasi produk yang sesuai dengan kebutuhan konsumen.

Quality Function Deployment (QFD) adalah metode perencanaan yang digunakan untuk mendiskripsikan keinginan pelanggan dan menerjemahkannya kedalam tahapan strategis sehingga menghasilkan produk dengan karakteristik yang sesuai dengan keinginan konsumen (Ali Akram, Iqbal Mahmud, Riad Bin Ashraf, Awal, \& Talapatra, 2018; Keshtkaran, Hashemi, Kharazmi, \& Abbasi, 2016). QFD juga dikenal sebagai sebuah sistem yang digunakan untuk mendesaik produk atau jasa yang melibatkan seluruh fungsi organisasi industri dan pemasok dengan menggunakan tahapan-tahapan yang mampu menerjemahkan kebutuhan konsumen ke dalam kebutuhan teknis yang tepat (Oakland \& Marosszeky, 2006).

QFD dikenalkan pada tahun 1970-an di Jepang dan pada perkembangannya mampu memberikan kesuksesan bagi setiap organisasi industri yang menggunakannya, baik di Jepang seperti Toyota beserta pemasoknya maupun di luar Jepang seperti Hawleet-packard, General motor, dan Ford. QFD juga sudah diimplementasikan pada berbagai bidang usaha, seperti pertanian (Djekic et al., 2017), makanan (Aleshkov et al., 2019; Dvoryaninova, Alekhina, Kutsova, Kosenko, \& Pegina, 2020), perhotelan (Ali Akram et al., 2018), kesehatan (Keshtkaran et al., 2016), asuransi (Kecek \& Akinci, 2016), pendidikan (Karanjekar, Lakhe, \& Deshpande, 2019; Matorera \& Fraser, 2016), konstruksi (Paul \& Seth, 2017), teknologi informasi (Han, Jung, \& Tom Dieck, 2019) dan berbagai industri manufaktur (Kato \& Katsumata, 2016; A. W. Lee, Lin, Kuo, \& Lee, 2017; Tsegaw, Balasundaram, \& Kumar, 2017; Ullah \& Ali, 2017).

Untuk bidang manufaktur, penggunaan QFD masih seputar pengembangan produk setengah jadi maupun produk akhir, seperti aki mobil (Darmawan et al., 2017), sepeda (Hidayati, Iftadi, \& Rochman, 2013), smart watch (A. W. Lee et al., 2017), kursi (Kato \& Katsumata, 2016), dan kabin kereta cepat (Chin, Yang, Chan, Tsui, \& Li, 2019). Literatur yang membahas tentang penggunaan QFD pada proses pengembangan material dasar terkait dengan komposisi kimia maupun mekanik dari suatu produk khususnya pada produk spring steel masih terbatas. Weijie (2020) memberikan usulan bahwa QFD dapat digunakan untuk mendesain dan membuat inovasi produk yang bersifat propertis mekanik. Oleh karena itu, penelitian ini akan mengisi kesenjangan tersebut dengan menggunakan kerangka QFD sebagai metode untuk mengembangkan komposisi kimia maupun sifat mekanik produk spring steel yang berasal dari material HRC tipe SPHC dan SS400.

\section{Metode Penelitian}

Metode yang digunakan pada penelitian ini menggunakan tahapan dari kerangka pemikiran Quality Function Deployment (QFD). Langkah penelitian ini berdasarkan tujuh langkah utama QFD yang diadopsi dari Tsegaw et al. (2017) dan Keshtkaran et al. (2016), yaitu (1) identifikasi kebutuhan konsumen (customer requirements), (2) penentuan matriks bobot prioritas dari kebutuhan konsumen (customer requirements priority matrix/weight importance), (3) penentuan kebutuhan teknis (technical requirements), (4) penentuan matriks hubungan antara kebutuhan konsumen dengan kebutuhan teknis (customer requirements and technical specifications relationship matrix), (5) penentuan matriks korelasi antar kebutuhan teknis (technical requirements' relationship matrix), (6) penentuan matriks perencanaan dan bobot (planning matrix and customer requirements priority matrix), (7) penentuan target dan bobot dari kebutuhan teknis (technical requirements priority matrix and target spesifications). Tahapan tersebut secara grafis dapat dilihat pada Gambar 1. Kemudian, penelitian dilanjutkan dengan proses pembuatan (manufacturing) produk (specimen) spring steel pada skala laboratorium.

Setelah dilakukan pembuatan produk kemudian dilakukan pengecekan komposisi kimia dan mekanik dengan mengacu pada standar internasional untuk produk tersebut. Standar yang digunakan untuk produk spring steel adalah Japan Internatioan Standard (JIS) G 4801 Spring steels grade SUP9A (JSSE, 2007).

\subsection{Identifikasi kebutuhan konsumen}

Penentuan kebutuhan konsumen dilakukan dengan menggunakan metode focused group discussion (FGD) kepada perusahaan yang menggunakan produk spring steel. Kategori pasar untuk produk tersebut adalah captive markets, maka pelanggan yang terlibat pada penelitian ini hanya 1 (satu) perusahaan yang merupakan perusahaan pengguna dari produk spring steel. Representasi perusahan tersebut adalah bagian Marketing ( 3 orang) dan bagian Research and Development (R\&D) berjumlah 5 orang ( 1 orang manager dan 3 orang project engineer). Ada dua pertanyaan terbuka yang digunakan dalam FGD ini yaitu (1) apa yang diharapkan dan (2) apa yang tidak diharapkan pada produk ini. Berdasarkan jawaban dari pertanyaan terbuka 
tersebut kemudian dilakukan stratifikasi jawaban. Selain itu, kebutuhan konsumen juga mempertimbangkan spesifikasi teknis pada technical requirements dari produk tersebut.

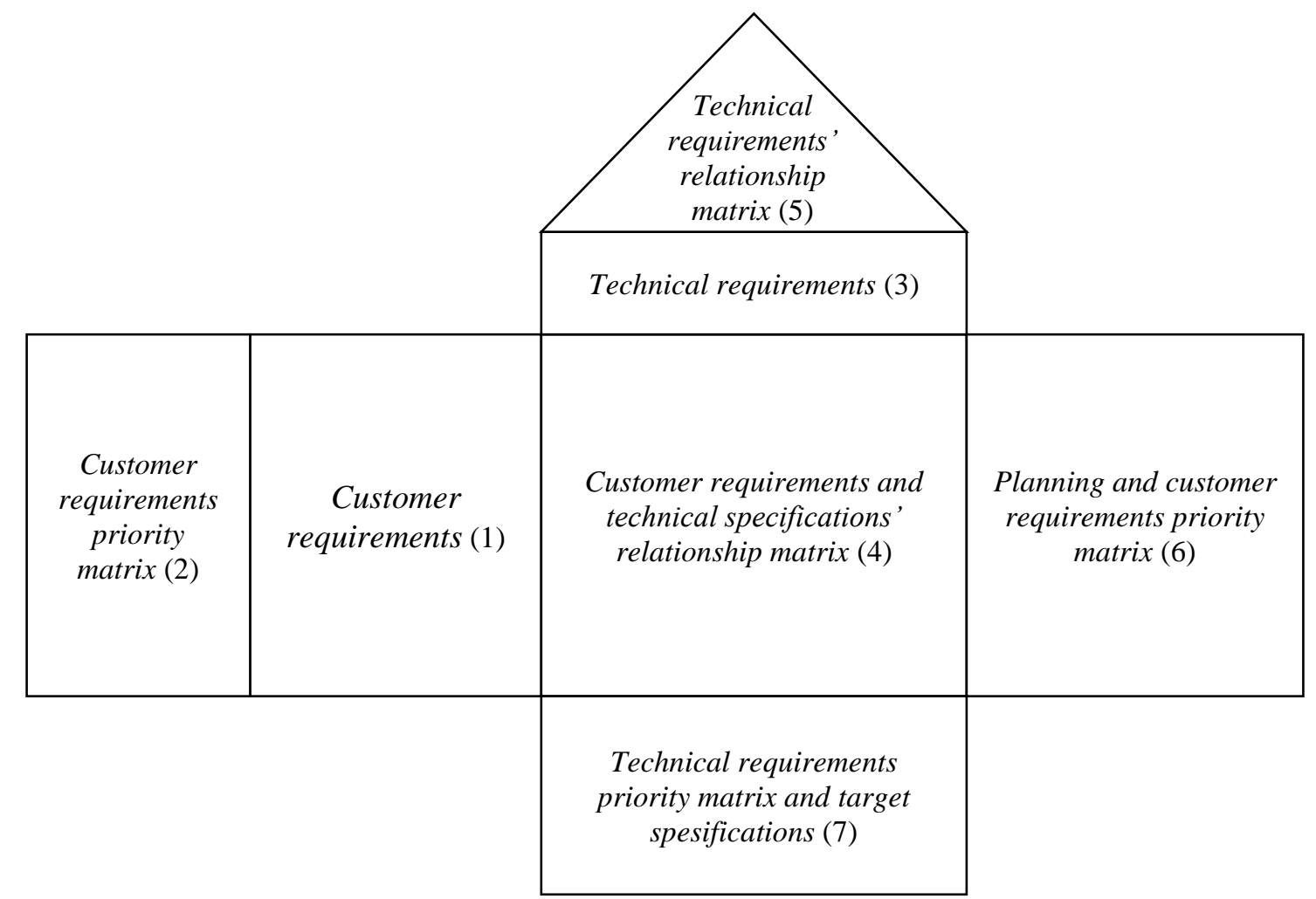

Gambar 1. Quality Function Deployment Method

\subsection{Penentuan matriks prioritas dari kebutuhan konsumen}

Pada tahapan ini dilakukan survei menggunakan instrumen kuisioner dengan jumlah pertanyaan 10 item yang didapatkan dari identifikasi kebutuhan konsumen. Skala yang digunakan dalam kuisioner adalah skala likert dengan 1-5 (1=Sangat tidak penting, $2=$ tidak penting, $3=$ cukup penting, $4=$ penting, $5=$ sangat penting). Setelah data dikumpulkan, selanjutnya dilakukan uji validitas dan reliabilitas ítem dengan tingkat signifikansi (a) $5 \%$.

\subsection{Penentukan kebutuhan teknis}

Setelah didapatkan kebutuhan konsumen, langkah berikutnya adalah diskusi dengan tim R\&D dari perusahaan untuk mendapatkan kebutuhan teknis dengan pendekatan pohon klasifikasi. Kebutuhan teknis ini mempertimbangkan pada kemampuan perusahaan.

\subsection{Penentuan matriks hubungan antara kebutuhan konsumen dengan kebutuhan teknis}

Untuk matriks hubungan antara kebutuhan konsumen dengan kebutuhan teknis, langkah yang dilakukan adalah diskusi dengan tim $\mathrm{R} \& \mathrm{D}$ dan tim project engineer untuk menentukan hubungan tersebut. Hubungan tersebut ditentukan kedalam empat level yaitu tidak ada hubungan $(\mathrm{X})$, hubungan lemah $(\Delta)$, hubungan moderat (O), dan hubungan kuat ( $)$, di mana masing-masing memiliki bobot nilai 0, 1, 3 dan 9 .

\subsection{Penentuan matriks korelasi antar kebutuhan teknis}

Penenentuan hubungan matriks korelasi antar kebutuhan teknis dengan melalui diskusi melibatkan tim R\&D dan tim project engineer sebagaimana pada tahapan empat. Hubungan dinyatakan ke dalam lima level, yaitu positif kuat, positif sedang, tidak ada hubungan, negatif sedang, dan negatif kuat.

\subsection{Penentuan matriks perencanaan dan bobot}

Pada tahapan ini diperlukan nilai competitive satisfaction performance (CSP), goal, improvement ratio, sales point. Pada akhirnya akan dilakukan pembobotan sesuai dengan rumus 1 dan perankingan sesuai dimulai dari nilai tertinggi. CSP didapatkan dengan menyebarkan kuisioner kepada konsumen sebagaimana pada langkah 2, sedangkan nilai goal dan sales point didapatkan dengan diskusi terhadap tim R\&D dan project engineer.

Row weight $_{i}=W_{i} \cdot I_{i} \cdot S_{i}$

Di mana,

$W_{i} \quad:$ weight importance baris ke- $i$;

$I_{i} \quad$ : improvement ratio baris ke- $i$ dan

$S_{i} \quad:$ sales point baris ke- $i$. 


\subsection{Penentuan target spesifikasi dan bobot dari kebutuhan teknis}

Penentuan target spesifikasi dilakukan melalui diskusi dengan tim R\&D dan project engineer. Sedangkan bobot kebutuhan teknis dihitung dengan mengikuti rumus 2 .

Column weight $_{j}=\sum_{i=0}^{n} W_{i} \cdot R_{i, j}$

Di mana,

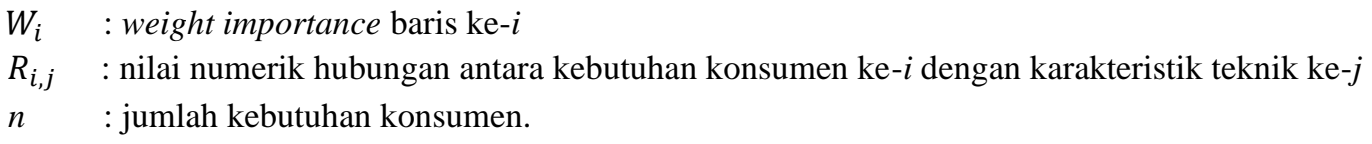

\section{Hasil dan Pembahasan}

\subsection{Model QFD untuk Spring Steel}

Identifikasi kebutuhan konsumen didapatkan 10 item untuk produk spring steel yaitu: (1) kekerasan produk spring steel, (2) mampu bentuk, (3) tahan karat, (4) tahan aus, (5) tahan panas, (6) kuat Tarik, (7) ukuran produk, (8) inforasi komposisi vahan (9) harga, (10) mudah didapat.

Selanjutnya, 10 item tersebut kemudian dilakukan uji validitas dan reliabilitas. Hasil uji tersebut didapatkan bahwa 10 item dinyatakan valid dengan $r$ hitung $(0,69-0,91)>r$ tabel $(0,62)$ dan reliable dengan cronbach's alpha 0,93 . Hasil ini menunjukkan bahwa kebutuhan konsumen terhadap produk spring steels lebih mengarah pada kualitas material yang baik, hal ini dapat dilihat dari 10 item tersebut, 9 item mengacu pada kualitas produk.

Berdasarkan 10 item pertanyaan tersebut, selanjunya dilakukan survei menggunakan skala likert, untuk mengetahui nilai prioritas dan nilai competive satisfaction performance (CSP) sesuai dengan persepsi konsumen. Hasil rekapitulasi dari 10 item pertanyaan kemudian dibuat nilai rata-rata. Hasil tersebut sebagaimana yang ditampilkan pada Tabel 1.

Tabel 1. Nilai prioritas dan CSP dari kebutuhan konsumen

\begin{tabular}{llcc}
\hline No. & Customer requirments & Prioritas & CSP \\
\hline 1. & Kekerasan Produk Spring Steel & 3,0 & 3,1 \\
2. & Mampu bentuk & 3,5 & 3,2 \\
3. & Tahan Karat & 2,9 & 2,9 \\
4. & Tahan Aus & 2,9 & 3,0 \\
5. & Tahan Panas & 2,7 & 3,1 \\
6. & Kuat Tarik & 3,4 & 3,1 \\
7. & Ukuran Produk & 3,0 & 2,8 \\
8. & Terdapat Informasi Komposisi Bahan & 3,0 & 3,0 \\
9. & Tingkat Harga & 3,0 & 3,4 \\
10. & Mudah Didapat & 3,1 & 3,2 \\
\hline
\end{tabular}

Berdasar dari kebutuhan konsumen tersebut kemudian dilakukan análisis dengan menggunakan pohon klasifikasi untuk mendapatkan kebutuhan teknis. Metode yang digunakan adalah diskusi dengan tim R\&D dan project engineer. Hasil yang didapatkan untuk kebutuhan teknis ini dikonsultasikan untuk dilihat kelayakan saat dijalankan sesuai dengan sumber daya yang dimiliki oleh perusahaan pengembang. Kebutuhan teknis akhir tersebut dapat dilihat pada Gambar 2. Kebutuhan teknis yang didapatkan yaitu heat treatment, kandungan Kandungan Carbon (C), Chrome (Cr), Silicon (Si), Phosporus (P), Manganum (Mn), Nickel (Ni), Cuprum $(\mathrm{Cu})$, dan Sulphur $(\mathrm{S})$, rolling process, desain kemasan, biaya manufaktur, biaya material, transportasi dan ketersediaan sumber daya alam (SDA). 


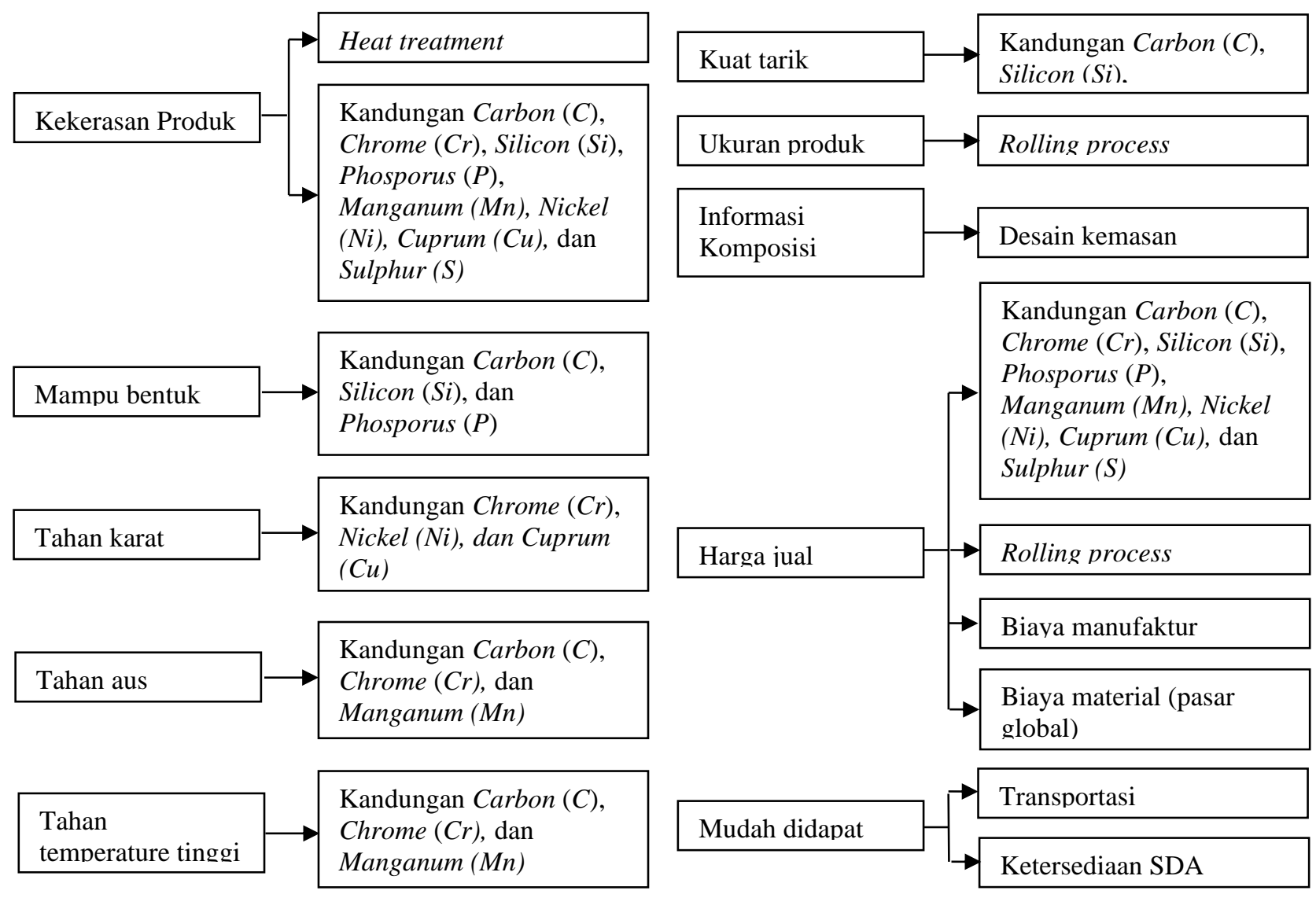

Gambar 2. Pohon klasifikasi kebutuhan konsumen dan kebutuhan teknis

Mengacu pada 7 tahapan QFD tersebut, maka didapatkan hasil QFD untuk produk spring steel sebagaimana pada Gambar 3. Prioritas kebutuhan konsumen diurutkan berdasarkan nilai tertinggi dari masingmasing bobot kebutuhan, di mana kebutuhan konsumen yang tertinggi adalah pada mampu bentuk $(5,4)$ harga jual $(5,2)$, kuat Tarik $(3,7)$, kekerasan $(2,9)$, mudah didapat $(2,1)$, tahan aus $(1,8)$, tahan karat $(1,6)$, ukuran produk $(1,0)$, informasi komposisi bahan $(0,8)$, tahan panas/temperatur tinggi $(0,4)$.

Target spefisikasi technical requirements didapatkan dari hasil diskusi dengan tim $\mathrm{R} \& \mathrm{D}$ dan project engineer serta mengacu pada Japan International Standard (JIS) untuk JIS G 4801 Spring steels grade SUP9A. Sedangkan arah pengembangan (direction of improvement) untuk technical requirements disesuaikan dengan kebutuhan pengembangan dan standar spesifikasi. Arah pengembangan proses heat treatment, kandungan Carbon (C), Silicon (Si), Manganum (Mn), Nickel (Ni), Cuprum (Cu), proses rolling dan kondisi pasar global dilakukan perbaikan sesuai dengan target yang ditentukan. Sedangkan kandungan Chrome (Cr), desain kemasan, kondisi transportasi, ketersediaan sumber daya alama diupayakan perbaikan untuk selalu meningkat. Sedangkan sebaliknya, untuk kandungan Phosporus (P), Sulphur (S), biaya manufaktur perbaikan akan dilakukan dengan menurunkan nilai yang ada agar menjadi lebih baik.

Berdasarkan pada perhitungan bobot dari kebutuhan teknis diperoleh bahwa nilai tertinggi adalah kandungan Carbon $(359,1)$ diikuti oleh Chrome (78,3), Silicon $(74,1)$, Phosporus $(74,1)$, Manganum $(62,5)$. Hasil dari bobot tersebut juga mengindikasikan bahwa unsur material menjadi prioritas dalam menentukan kualitas pada produk sring steel. Fokus pengembangan berikutnya adalah pada pengembangan material dasar yang dapat membuat produk spring steel sesuai dengan target produk yang diinginkan oleh konsumen. Hal tersebut dikarenakan beberapa fungsi dan fitur produk menjadi pertimbangan seorang konsumen dalam memilih dan menentukan pembelian. Sebagaimana Kim, Wong, Chang, \& Park (2016) menjelaskan bahwa segala fitur yang dimiliki oleh produk yang dijual dapat memberikan pengaruh signifikan terhadap loyalitas konsumen. Dengan demikian, pengembangan produk ini akan dikonsentrasikan pada kualitas material dasar produk spring steel. 


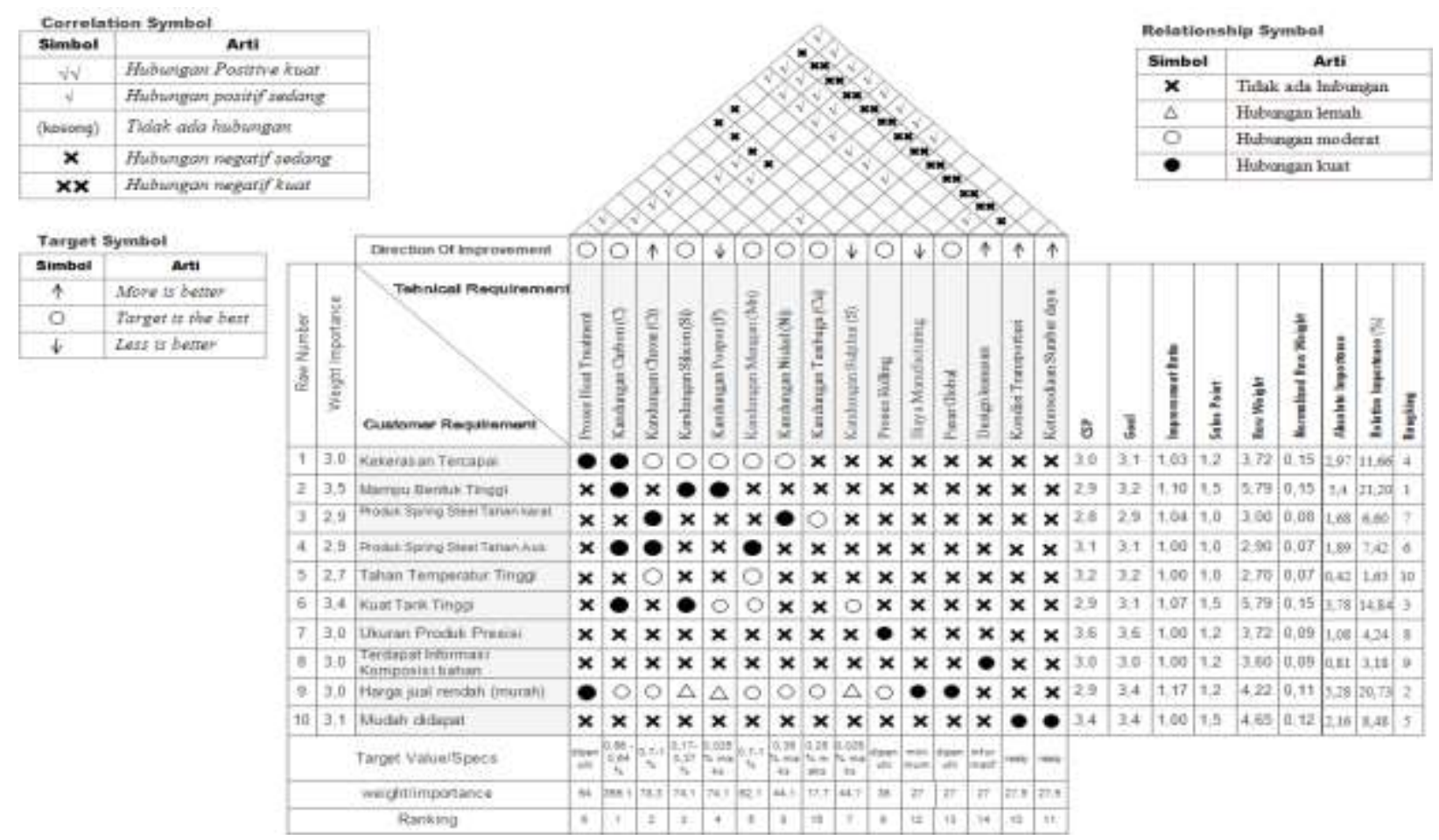

Gambar 3. QFD untuk produk spring steel

\subsection{Proses manufaktur Spring Steel}

Hasil QFD tersebut kemudian dilanjutkan dengan tahapan manufaktur dengan skala laboratorium. Tahapan manufaktur ini dengan melalui beberapa proses yaitu: melting (peleburan), casting (pencetakan), hot rolling (penggulungan), heat treatment (proses pemanasan) dan testing (pengujian). Pada proses melting ini menggunakan Vaccuum Induction Furnace (VIF). Material yang digunakan adalah campuran scrap material HRC (tipe SPHC dan SS400) sebesar $110 \mathrm{Kg}$ dan Ferroalloy dengan komposisi sebagaimana pada Tabel 2.

Tabel 2. Komposisi Material

\begin{tabular}{ccc}
\hline Komposisi & $\begin{array}{c}\text { HRC } \\
\text { Type SPHC }\end{array}$ & $\begin{array}{c}\text { HRC } \\
\text { Type SS400 }\end{array}$ \\
\hline $\mathrm{C}$ & 0.048 & 0.162 \\
$\mathrm{Si}$ & 0.010 & 0.016 \\
$\mathrm{Mn}$ & 0.280 & 0.927 \\
$\mathrm{P}$ & 0.0110 & 0.0161 \\
$\mathrm{~S}$ & 0.0190 & 0.0036 \\
$\mathrm{Cr}$ & 0.037 & 0.010 \\
$\mathrm{Mo}$ & 0.0001 & 0.001 \\
$\mathrm{Ni}$ & 0.0330 & 0.0490 \\
$\mathrm{~V}$ & 0.0001 & 0.0003 \\
$\mathrm{Cu}$ & 0.0760 & 0.007 \\
$\mathrm{Ti}$ & 0.0010 & 0.0001 \\
\hline
\end{tabular}

Untuk mencapai target komposisi kimia dari spring steel SUP9A perlu dilakukan perhitungan komposisi berat charging scrap, komposisi kimia campuran, dan perhitungan penambahan ferroalloy.

Kemudian berikut ini merupakan perhitungan komposisi kimia pencampuran bahan scrap di tunjukan pada Tabel 3. Komposisi tersebut belum sesuai dengan spring steel SUP9A sehingga perlu penambahan ferroalloy dengan pendekatan perhitungan.

Perhitungan akurat terhadap penambahan ferroalloy diperlukan untuk mendapatkan prediksi penambahan feroalloy sesuai target komposisi kimia produk. Penambahan ferroalloy sangat dipengaruhi oleh kadar ferroalloy, efisiensi dan yield dari ferroalloy. Berikut ini adalah hasil dari perhitungan penambahan alloy sebagai disajikan pada Tabel 4. 
Tabel 3. Hasil perhitungan komposisi kimia pencampuran bahan scrap

\begin{tabular}{cc}
\hline Komposisi & Initial Composition \\
\hline $\mathbf{C}$ & 0.110 \\
$\mathbf{S i}$ & 0.039 \\
$\mathbf{M n}$ & 0.633 \\
$\mathbf{P}$ & 0.014 \\
$\mathbf{S}$ & 0.011 \\
$\mathbf{C r}$ & 0.022 \\
$\mathbf{M o}$ & 0.0001 \\
$\mathbf{N i}$ & 0.042 \\
$\mathbf{V}$ & 0.0001 \\
$\mathbf{C u}$ & 0.0680 \\
$\mathbf{T i}$ & 0.0010 \\
\hline
\end{tabular}

Tabel 4. Penambahan Ferroalloy $(g)$

\begin{tabular}{lllllllll}
\hline Total & SPHC & SS400 & $\begin{array}{l}\text { Target } \\
\text { /Ferroalloy }\end{array}$ & C(g) & FeSi $(\boldsymbol{g})$ & FeMn $(\boldsymbol{g})$ & FeCr $(\boldsymbol{g})$ & FeNi(g) \\
\hline $\mathbf{1 1 0}$ & 90 & 20 & Min & 715 & 225 & 29 & 1229 & 464 \\
& & & Average & 770 & 396 & 222 & 1587 & 530 \\
& & & Max & 825 & 568 & 608 & 1619 & 584 \\
\hline
\end{tabular}

Untuk proses berikutnya adalah Casting. Pada proses ini material tersebut dicetak dari suhu $1560{ }^{\circ} \mathrm{C}$ sampai mencapai suhu kamar $100{ }^{\circ} \mathrm{C}$. Casting yang dihasilkan memiliki dimensi $110 \mathrm{~mm}$ x $110 \mathrm{~mm}$ x 650 $\mathrm{mm}$. Kemudian diproses ke dalam hot rolling dengan menggunakan parameter temperatur $1200{ }^{\circ} \mathrm{C}$ dengan waktu yang sudah disesuaikan dengan standar parameter. Setelah proses rolling dilakukan heat treatment dengan temperatur $830-860^{\circ} \mathrm{C}$ dengan waktu sesuai standar parameter. Produk (specimen) yang dihasilkan sebagaimana pada Gambar 4.

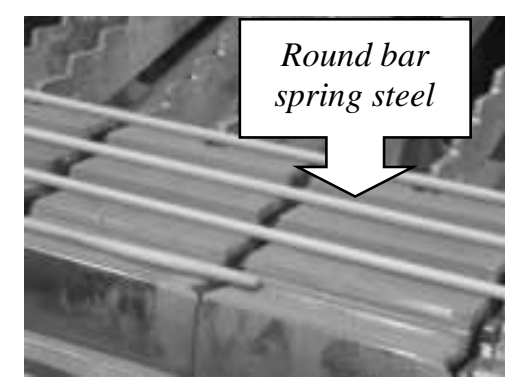

Gambar 4. Round bar spring steels

Produk yang dihasilkan tersebut, kemudian dilakukan pengecekan komposisi kimia. Hasil pengecekan komposisi kimia dapat dilihat pada Tabel 5, di mana satu unsur Kimia Chrome ( $\mathrm{Cr}$ ) sebesar 1.05\%, komposisi yang dihasilkan tersebut melebihi $0.05 \%$ dari angka yang diharapkan (standar $=0.70-1.00$ ). Fungsi Chrome pada spring steel adalah untuk menambah tingkat kekerasan material dan umur material (J. W. Lee, 2005). Angka komposisi Chrome tersebut memiliki pengaruh terhadap kekerasan material produk spring steel. Dengan demikian untuk memastikan hal tersebut selanjutnya dilakukan uji mekanik.

Tabel 5. Hasil pengecekan produk (specimen)

\begin{tabular}{ccc}
\hline Komposisi & JIS G4801 Std & Nilai \\
\hline $\mathbf{C}$ & $0.56-0.64$ & 0.58 \\
$\mathbf{S i}$ & $0.17-0.37$ & 0.24 \\
$\mathbf{M n}$ & $0.70-1.00$ & 0.90 \\
$\mathbf{P}$ & $>0.04$ & 0.01 \\
$\mathbf{S}$ & $>0.04$ & 0.01 \\
$\mathbf{C r}$ & $0.70-1.00$ & 1.05 \\
$\mathbf{N i}$ & $>0.35$ & 0.33 \\
\hline
\end{tabular}


Pengujian (testing) mekanik dilakukan untuk produk yang dihasilkan. Uji yang digunakan adalah dengan uji tarik dan uji kekerasan sesuai dengan acuan standar pengujian. Hasil uji tarik dapat dilihat pada Tabel 6, di mana hasil uji tarik menunjukan hasil produk spring steel masuk kedalam standar JIS G4801. Sedangkan uji kekerasan dapat dilihat pada Tabel 7, hasil pengujian kekerasan pada produk spring steel menunjukan kekerasan produk sesuai dengan standar yang ditetapkan dalam JIS G4801. Dengan demikian, usulan produk spring steel sebagai produk inisial dapat dikatakan layak.

Tabel 6. Hasil uji tarik produk spring steel

\begin{tabular}{lcc}
\hline \multicolumn{1}{c}{ Nilai Uji Tarik } & JIS G4801 Std & Hasil Percobaan \\
\hline Batas ulur $\left(\mathrm{kgf} / \mathrm{mm}^{2}\right)$ & $117.87-119.52$ & 118.18 \\
Kuat tarik $\left(\mathrm{kgf} / \mathrm{mm}^{2}\right)$ & $126.34-128.85$ & 126.86 \\
Regangan $(\%)$ & $9.8-11.3$ & 10 \\
\hline
\end{tabular}

Tabel 7. Hasil uji kekerasan produk spring steel

\begin{tabular}{ccc}
\hline Nilai Uji Kekerasan & JIS G4801 Std & Hasil Percobaan \\
\hline Hardness Vickers $(H V)$ & $376-458$ & 380 \\
\hline
\end{tabular}

\section{Simpulan}

Pengembangan produk Spring steel dari material sisa (scrap) dari campuran HRC tipe SPHC dan SS400 dengan menggunakan kerangka berpikir QFD dapat diimpelementasikan dengan baik. QFD dapat digunakan untuk membantu melakukan prioritas keinginan konsumen pada sebuah produk, sehingga produk yang dihasilkan dapat memberikan hasil yang sesuai dengan kebutuhan konsumen. Sebagaimana pernyataan dari Chin et al. (2019) bahwa hasil dari QFD dapat menjadi referensi yang berguna bagi perancang dan otoritas manajemen untuk meningkatkan kualitas dan mencapai kepuasan pelanggan. QFD juga dapat membantu menentukan secara spesifik dari bagian produk apa yang harus dikembangkan (Donnici, Frizziero, Francia, Liverani, \& Caligiana, 2019). Pada penelitian ini, QFD dapat digunakan menentukan fokus pengembangan produk spring steel, di mana fokus pengembangan tersebut adalah pada bahan baku yang digunakan.

Hasil penelitian ini menghasilkan produk sesuai dengan spesifikasi yang diharapkan konsumen dengan komposisi kimia dan mekanik spring steel yang dapat memenuhi standar JIS G4801. Adapun kekuranganganya adalah untuk komposisi Chrome $(\mathrm{Cr})$ yang melebihi angka yang diharapkan dari standar JIS G4801, tetapi melalui uji mekanik didapatkan bahwa produk tersebut memenuhi standar yang diharapkan. Hal tersebut dapat dilihat dari hasil dari uji tarik dan uji kekerasan, di mana kedua hasil uji tersebut dinyatakan bahwa produk sesuai dengan standar yang ditargetkan.

Kontribusi penelitian ini adalah memberikan pemahaman konseptual tentang penerapan kerangka QFD untuk pengembangan material dasar sehingga menghasilkan produk yang sesuai dengan kebutuhan konsumen. Selain itu, langkah pengembangan produk spring steel yang didapatkan pada penelitian ini dapat digunakan sebagai rujukan untuk pengembangan produk spring steel dengan menggunakan material HRC.

Keterbatasan pada penelitian ini adalah pengembangan penelitian masih terbatas pada konsumen penggunaan yaitu 1 perusahaan, sehingga masih diperlukan penelitian dengan melibatkan berbagai perusahaan pengguna produk spring steel sehingga menghasilkan studi yang lebih komprehensif. Begitu juga dengan produk spring steel yang dihasilkan masih sebatas produk inisial, sehingga dapat dikembangkan ke dalam analisis kualitas produk dengan menggunakan pendekatan Design For Sig Sigma (DFSS) maupun Design Failure Modes and Effects Analysis (DFMEA) maupun studi kelayakan produk dengan menggunakan pendekatan analisis biaya.

\section{Ucapan Terima Kasih}

Penulis menyampaikan terima kasih kepada Universitas Serang Raya dan perusahaan baja di Kota Cilegon yang sudah mendukung program penelitian ini. 


\section{DaftarPustaka}

Aleshkov, A. V., Zhebo, A. V., Kalenik, T. K., \& Solovev, D. B. (2019). Quality Function Deployment Method for Development of Innovative Production. Advances in Economics, Business and Management Research, 47(Iscfec 2018), 603-608. https://doi.org/10.2991/iscfec-18.2019.150

Ali Akram, M., Iqbal Mahmud, M., Riad Bin Ashraf, S., Awal, S., \& Talapatra, S. (2018). Enhancing the Healthcare Service Using Quality Function Deployment and Database Management System in the Outpatient Department of a Government Hospital of Bangladesh. International Research Journal of Engineering and Technology, 5(4), 2022-2029. Retrieved from www.irjet.net

Chin, K. S., Yang, Q., Chan, C. Y. P., Tsui, K. L., \& Li, Y. lai. (2019). Identifying passengers' needs in cabin interiors of high-speed rails in China using quality function deployment for improving passenger satisfaction. Transportation Research Part A: Policy and Practice, 119(October 2018), 326-342. https://doi.org/10.1016/j.tra.2018.12.004

Darmawan, H., Purba, H. H., Rezeki, R., Hidayat, N., Siregar, A. R., Retna, F., \& Aisyah, S. (2017). Product development strategy with quality function deployment approach: A case study in automotive battery. Management Science Letters, 7(12), 601-610. https://doi.org/10.5267/j.msl.2017.8.005

Djekic, I., Vunduk, J., Tomašević, I., Kozarski, M., Petrovic, P., Niksic, M., ... Klaus, A. (2017). Application of quality function deployment on shelf-life analysis of Agaricus bisporus Portobello. LWT - Food Science and Technology, 78, 82-89. https://doi.org/10.1016/j.lwt.2016.12.036

Donnici, G., Frizziero, L., Francia, D., Liverani, A., \& Caligiana, G. (2019). Innovation design driven by QFD and TRIZ to develop new urban transportation means. Australian Journal of Mechanical Engineering, OO(00), 1-17. https://doi.org/10.1080/14484846.2019.1615259

Dvoryaninova, O. P., Alekhina, A. V., Kutsova, A. E., Kosenko, I. S., \& Pegina, A. N. (2020). Using quality function deployment for improving fish preserves technology. IOP Conference Series: Earth and Environmental Science, 422(1). https://doi.org/10.1088/1755-1315/422/1/012048

Han, D. I. D., Jung, T., \& Tom Dieck, M. C. (2019). Translating Tourist Requirements into Mobile AR Application Engineering Through QFD. International Journal of Human-Computer Interaction, 35(19), 1842-1858. https://doi.org/10.1080/10447318.2019.1574099

Hidayati, F., Iftadi, I., \& Rochman, T. (2013). Design and development of vegetable seller's bike by using anthropometry approach and quality function deployment method (QFD). Performa, 12(2), 137-146.

JSSE. (2007). Materials for springs. (Y. Yamada \& T. Kuwabara, Eds.). Berlin: Springer Berlin Heidelberg New York.

Karanjekar, S. B., Lakhe, R. R., \& Deshpande, V. S. (2019). A comprehensive quality function deployment model for improving academics of technical institutes. International Journal of Electrical Engineering Education, O(0), 1-24. https://doi.org/10.1177/0020720919833053

Kato, T., \& Katsumata, S. (2016). Human design technology using quality function deployment and its application. Bulletin of JSSD, 62(5), 31-40.

Kecek, G., \& Akinci, O. C. (2016). Quality Function Deployment and an Application in an Insurance Company. International Journal of Academic Research in Business and Social Sciences, 6(4). https://doi.org/10.6007/ijarbss/v6-i4/2085

Keshtkaran, A., Hashemi, N., Kharazmi, E., \& Abbasi, M. (2016). Applying Quality Function Deployment Model in Burn Unit Service Improvement. Journal of Burn Care and Research, 37(5), e440-e452. https://doi.org/10.1097/BCR.0b013e3182920d55

Kim, M. K., Wong, S. F., Chang, Y., \& Park, J. H. (2016). Determinants of customer loyalty in the Korean smartphone market: Moderating effects of usage characteristics. Telematics and Informatics, 33(4), 936949. https://doi.org/10.1016/j.tele.2016.02.006

Krishnan, V., \& Ulrich, K. T. (2001). Product development decisions: A review of the literature. Management Science, 47(1), 1-21. https://doi.org/10.1287/mnsc.47.1.1.10668

Lee, A. W., Lin, G. T. R., Kuo, W. H., \& Lee, S. J. (2017). The application of quality function deployment to smartwatches the house of quality for improved product design. PICMET 2017 - Portland International Conference on Management of Engineering and Technology: Technology Management for the Interconnected World, Proceedings, 2017-Janua(March), 1-6. https://doi.org/10.23919/PICMET.2017.8125413

Lee, J. W. (2005). Microstructures and mechanical properties evaluation of hard chromized austenitic Fe-MnAl alloys. Applied Surface Science, 244(1-4), 248-251. https://doi.org/10.1016/j.apsusc.2004.10.134

Matorera, D., \& Fraser, W. J. (2016). The feasibility of quality function deployment (QFD) as an assessment and quality assurance model. South African Journal of Education, 36(3), 1-13. https://doi.org/10.15700/saje.v36n3a1275

Oakland, J., \& Marosszeky, M. (2006). Total Quality in The Construction Supply Chain (First Ed.). Oxford: Elsevier Ltd.

Paul, V. K., \& Seth, V. (2017). Benchmarking and objective selection of technologies for housing in India 
using quality function deployment. Journal of Construction in Developing Countries, 22, 63-78. https://doi.org/10.21315/jcdc2017.22.supp1.4

Polak, P., \& Jurczyk-Bunkowska, M. (2017). Employing the quality function deployment (QFD) method to support knowledge management in innovation process planning. Online Journal of Applied Knowledge Management, 5(2), 92-105. https://doi.org/10.36965/ojakm.2017.5(2)92-105

Tsegaw, F. G., Balasundaram, K., \& Kumar, M. S. S. (2017). A Case Study on Improvement of Conceptual Product Design Process by Using Quality Function Deployment. International Journal of Advances in Scientific Research and Engineering (Ijasre), 03(4), 1-10. Retrieved from http://www.ijasre.net/uploads/1/2807_pdf.pdf

Ullah, H., \& Ali, A. (2017). Design and Development of Mobile Phone Using Quality Function Deployment. International Journal of Engineering Materials and Manufacture, 2(1), 1-10. https://doi.org/10.26776/ijemm.02.01.2017.01

Weijie, J. (2020). Research and Application of Mechanical Product Design Process Based on QFD and TRIZ Integration Research and Application of Mechanical Product Design Process Based on QFD and TRIZ Integration. In Journal of Physics: Conference Series (pp. 1-6). https://doi.org/10.1088/1742$6596 / 1544 / 1 / 012088$ 